\title{
Effects of dietary energy density on nutrient digestibility, performance and carcass characteristics of Morada Nova lambs
}

\section{Efeitos da densidade de energia da dieta sobre a digestibilidade dos nutrientes, o desempenho e as características de carcaça de cordeiros Morada Nova}

\author{
Marcus Roberto Goes Ferreira Costa ${ }^{1}$; Elzânia Sales Pereira ${ }^{2 *}$; \\ Patrícia Guimarães Pimentel ${ }^{3}$; Aderbal Marcos de Azevêdo Silva ${ }^{4}$; Pedro Veiga \\ Rodrigues Paulino ${ }^{5}$; Ivone Yurika Mizubuti ${ }^{6}$; Edson Luis de Azambuja Ribeiro ${ }^{6}$; \\ Andréa Pereira Pinto ${ }^{7}$; Danilo de Araújo Camilo ${ }^{8}$
}

\begin{abstract}
The trial was conducted with 48 Morada Nova lambs to evaluate the effects of different levels of metabolizable energy (ME) on nutrient digestibility and carcass characteristics. The animals were noncastrated and 2 months of age, with initial body weight (BW) averaging $12.05 \pm 1.81 \mathrm{~kg}$. The animals were assigned to a randomized block design with eight replications per block and five diets with increasing levels of metabolizable energy $(0.96,1.28,1.72,2.18$ and $2.62 \mathrm{Mcal} / \mathrm{kg} \mathrm{DM})$. Animals were weighed weekly to calculate the average daily gain (ADG). When the BW mean for a particular dietary treatment reached $25 \mathrm{~kg}$, the animals were slaughtered. Linear effect was observed for digestibility coefficient of $\mathrm{DM}, \mathrm{OM}, \mathrm{EE}, \mathrm{CP}, \mathrm{NDF}, \mathrm{TC}, \mathrm{FC}$ and NFC. The ADG presented linear increase $(\mathrm{P}<0.0001)$ with ME levels. The highest ADG observed was $135.98 \mathrm{~g} /$ day for the level of $2.62 \mathrm{Mcal} / \mathrm{kg} \mathrm{DM}$. The hot carcass weight, cold carcass weight, loss by cooling in kilogram and biological yield did not vary in function of ME levels with average values of $11.52 ; 11.03 ; 0.48$ and 57.25 , respectively. It was concluded that the incresead level of dietary energy influences nutrient digestibility and average daily gain of Morada Nova lambs during the growing period, without changing carcass traits.
\end{abstract}

Key words: Digestibility, growth, roughage: concentrate ratio

\section{Resumo}

O estudo foi conduzido com 48 cordeiros Morada Nova para avaliar os efeitos de diferentes níveis de energia metabolizável (EM) sobre a digestibilidade e características de carcaça. Os animais não foram castrados e apresentavam dois meses de idade, com peso médio corporal (PC) inicial de 12,05 $\pm 1,81$ $\mathrm{kg}$. Os animais foram distribuídos em delineamento de blocos ao acaso com oito repetições por bloco e cinco dietas com nívei crescentes de energia metabolizável $(0,96 ; 1,28 ; 1,72 ; 2,18$ e 2,62 Mcal $/ \mathrm{kg}$

${ }^{1}$ Prof. Dr. do Ensino Básico, Técnico e Tecnológico do IFCE, Campus Crateús, Crateús, CE. E-mail: mr.goes@gmail.com

${ }^{2}$ Prof $^{\mathrm{a}} \mathrm{Dr}^{\mathrm{a}}$ do Dept ${ }^{\mathrm{o}}$ de Zootecnia, Universidade Federal do Ceará, UFC, Av. Mister Hull, 2977, Fortaleza, CE. Pesquisadora do CNPq. E-mail: elzania@hotmail.com

${ }^{3}$ Prof $^{\mathrm{a}}$ Dr $^{\mathrm{a}}$ do Dept ${ }^{\mathrm{o}}$ de Zootecnia, Universidade Federal do Ceará, UFC, Fortaleza, CE. E-mail: pgpimentel@hotmail.com

${ }^{4}$ Prof. Dr. do Dept ${ }^{\circ}$ de Zootecnia, Universidade Federal de Campina Grande, UFCG, Patos, PB. E-mail: aderbal@cstr.ufcg.edu.br

${ }^{5}$ Prof. Dr. do Dept $^{\circ}$ de Zootecnia, Universidade Federal de Viçosa, Viçosa, UFMG, Viçosa, MG. E-mail: pveiga@ufv.br

${ }^{6}$ Profs. Drs. do Dept ${ }^{\circ}$ de Zootecnia, Universidade Estadual de Londrina, UEL, Londrina, PR. Pesquisadores do CNPq. E-mail: mizubuti@uel.br; elar@uel.br

${ }^{7}$ Prof $^{\mathrm{a}}$ Dr $^{\mathrm{a}}$ do Dept ${ }^{\mathrm{o}}$ de Zootecnia, Universidade Federal do Ceará, UFC, Fortaleza, CE. E-mail: deiapp@hotmail.com

${ }^{8}$ Discente de Doutorado do Dept ${ }^{\circ}$ de Zootecnia, Universidade Federal do Ceará, UFC, Fortaleza, CE. E-mail: danilocamilo@ yahoo.com.br

* Author for correspondence 
MS). Os animais foram pesados semanalmente para cálculo do ganho médio diário (GMD). Quando o PC médio para um determinado tratamento atingiu $25 \mathrm{~kg}$, os animais foram abatidos. Foi observado efeito linear para o coeficiente de digestibilidade da MS, MO, EE, PB, FDN, CT, CF e CNF. O GMD apresentou aumento linear $(\mathrm{P}<0,0001)$ com os níveis de EM. O maior GMD observado foi de 135,98 $\mathrm{g} /$ dia para o nível de $2,62 \mathrm{Mcal} / \mathrm{kg}$ MS. O peso de carcaça quente, peso de carcaça fria, perda por resfriamento em $\mathrm{kg}$ e rendimento biológico não variaram em função dos níveis de $\mathrm{EM}$, com valores médios de 11,52; 11,03; 0,48 e 57,25, respectivamente. Conclui-se que o incremento do nível de energia em dietas influencia a digestibilidade dos nutrientes e o ganho médio diário de cordeiros Morada Nova, durante o período de crescimento, sem alterar as características de carcaça.

Palavras-chave: Digestibilidade, crescimento, relação volumoso: concentrado

\section{Introduction}

The importance of small ruminants in the less developed region of the world as a source of animal protein and income is increasing. Morada Nova sheep has its origin of northeast of Brazil, and is adapted to the climatic conditions of this region. Morada Nova is explored for meat and skin production, which is very appraised by the international market (FERNANDES, 1992). At the present, this breed has a small population, and many breeders are focusing in individual performance in terms of weight gain and body weight in detriment to characteristics of productive and reproductive efficiency, leading to the false perception that breeds of bigger animals are undoubtedly better.

There is not much information on Morada Nova sheep in Brazil. Most studies on this breed are based on crossbreeding to produce heavier animals for meat (McMANUS; PAIVA, ARAÚJO, 2010). An alternative to improve the performance of these animals and produce heavier carcasses in lower age is to increase the energy density of diets in the finishing phase. Whereas the type of food influences animal growth and among the nutritional components, energy is the most limiting, the supply of energy diets contributes to increase the efficiency of animal growth (MAHGOUB; LU; EARLY, 2000). However, it is necessary to establish adequate levels of dietary energy that is sufficient to the nutritional requirements, but they are not provided in excess, because increase production costs, environmental impact and fat carcass deposition, which is depressed by consumers.
In addition to the carcass evaluation is essential to study the effects of dietary levels on voluntary intake and nutrient digestibility by lambs, because intake and digestibility interact each other and determine animal performance. In addition, the energy content of rations has great influence on animal performance, since animals consume food to maintain constant energy intake and, in this case, satiety factors is the caloric density of food (VAN SOEST, 1965). Therefore, further research is necessary to attempt to evaluate the intake and nutrients digestibility and also carcass characteristics from lambs. Thus, the objective of this work was to evaluate intake and nutrient digestibility, performance and carcass characteristics of Morada Nova lambs in feedlot, fed diets with increasing levels of metabolizable energy.

\section{Materials and methods}

\section{Experimental site}

This trial was carried out in Department of Animal Science at Federal University of Ceara, in Fortaleza, state of Ceara (CE), Brazil, from February to June 2010. Humane animal care and handling procedures were followed according to the University's Animal Care Committee.

\section{Animals, housing and experimental diets}

Forty non-castrated Morada Nova lambs, averaging $12.05 \pm 1.81 \mathrm{~kg}$ of body weight (BW) and 60 days of age at the beginning of this trial, were used. Initially, the lambs were identified, 
wormed and individually penned, with feeding troughs for feed and water. The lambs were allocated randomly to five treatments that consisted of increasing levels of metabolizable energy ( 0.96 ; $1.28 ; 1.72 ; 2.18$ and $2.62 \mathrm{Mcal} / \mathrm{kg} \mathrm{DM}$ ) obtained from different roughage:concentrate ratios (95:5, $80: 20,60: 40,40: 60$ and 20:80, respectively), whose source of roughage was Tifton 85 hay. Animals were fed individually ad libitum twice a day (08h00 and 16h00), allowing up to $10 \%$ of orts. The experimental design was a randomized block with eight replications. Recommendations of NRC
(2007) for experimental diets formulation, were used. The diets were fed as a total mixed ration and formulated to be isonitrogenous with $16 \%$ of CP (DM basis) for gain of $200 \mathrm{~g} /$ day, except for the 95:5 ratio, formulated to meet the maintenance requirement with $9 \%$ of $\mathrm{CP}$. The concentrates were constituted on ground corn, soybean meal, urea, sodium chloride, limestone, dicalcium phosphate and mineral premix. The chemical composition of ingredients is presented in Table 1 and the average composition of the experimental diets is presented in Table 2.

Table 1. Chemical composition of the ingredients ( $\mathrm{g} / \mathrm{kg} \mathrm{DM})$.

\begin{tabular}{lcccccccc}
\hline \multirow{2}{*}{ Nutrient } & Tifton 85 & Corn & Soybean & \multicolumn{5}{c}{ Concentrate $^{1}$} \\
\cline { 6 - 8 } & Hay & meal & meal & 1 & 2 & 3 & 4 & 5 \\
\hline Dry matter & 953.6 & 891.0 & 951.8 & 967.0 & 962.4 & 954.3 & 958.3 & 947.3 \\
Organic matter & 873.8 & 879.3 & 885.7 & 930.4 & 889.2 & 911.9 & 919.5 & 903.2 \\
Crude protein & 78.9 & 91.4 & 546.3 & 298.6 & 525.5 & 279.3 & 221.3 & 188.9 \\
Ether extract & 14.6 & 53.9 & 29.1 & 25.4 & 29.7 & 36.7 & 34.2 & 30.8 \\
Ash & 79.8 & 11.7 & 66.1 & 36.6 & 73.2 & 42.4 & 38.8 & 44.1 \\
Neutral detergent fiber & 754.0 & 433.7 & 154.3 & 128.7 & 132.0 & 142.9 & 140.6 & 145.8 \\
Acid detergent fiber & 447.2 & 82.8 & 145.4 & 96.7 & 75.2 & 44.0 & 48.6 & 47.2 \\
Lignin & 51.2 & 8.1 & 37.3 & 9.5 & 13.8 & 16.4 & 18.9 & 19.4 \\
Cellulose & 304.4 & 24.1 & 55.3 & 35.7 & 72.0 & 33.7 & 33.5 & 35.3 \\
Hemicellulose & 306.8 & 350.9 & 8.9 & 32.0 & 56.8 & 98.9 & 92.0 & 98.6 \\
Total carbohydrates & 826.7 & 842.9 & 358.4 & 675.1 & 393.6 & 662.0 & 680.6 & 693.7 \\
Fibrous carbohydrates & 701.3 & 138.8 & 104.2 & 96.0 & 99.5 & 110.7 & 95.3 & 104.0 \\
Non fibrous carbohydrates & 125.3 & 704.1 & 254.2 & 579.1 & 294.1 & 551.3 & 585.3 & 589.7 \\
\hline
\end{tabular}

${ }^{1}$ Concentrate 1: $5 \%$ of the diet with $0.96 \mathrm{Mcal} / \mathrm{kg}$ of DM; Concentrate 2: $20 \%$ of the diet with $1.28 \mathrm{Mcal} / \mathrm{kg}$ of DM; Concentrate 3: $40 \%$ of the diet with $1.72 \mathrm{Mcal} / \mathrm{kg}$ of DM; Concentrate $4: 60 \%$ of the diet with $2.18 \mathrm{Mcal} / \mathrm{kg}$ of DM; Concentrate $5: 80 \%$ of the diet with $2.62 \mathrm{Mcal} / \mathrm{kg}$ of DM.

Source: Elaboration of the authors. 
Table 2. Chemical composition of experimental diets.

\begin{tabular}{|c|c|c|c|c|c|}
\hline \multirow{2}{*}{ Ingredient } & \multicolumn{5}{|c|}{ Level of metabolizable energy (Mcal/kg DM) } \\
\hline & 0.96 & 1.28 & 1.72 & 2.18 & 2.62 \\
\hline Tifton 85 Hay & 95 & 80 & 60 & 40 & 20 \\
\hline Concentrate & 5 & 20 & 40 & 60 & 80 \\
\hline Corn meal $^{1}$ & 626.3 & 158.7 & 694.5 & 724.6 & 756.1 \\
\hline Soybean meal ${ }^{1}$ & 326.2 & 806.5 & 285.3 & 248.8 & 225.9 \\
\hline Urea $^{1}$ & 37.7 & 30.0 & 12.5 & 11.2 & 5.1 \\
\hline Limestone $^{1}$ & - & - & - & 5.4 & 6.6 \\
\hline Dicalcium phosphate $^{1}$ & - & - & - & - & 0.7 \\
\hline Sodium Chloride ${ }^{1}$ & 8.6 & 4.0 & 7.0 & 9.3 & 5.0 \\
\hline Mineral Premix ${ }^{1,2}$ & 1.2 & 0.8 & 0.7 & 0.7 & 0.6 \\
\hline Nutrient (g/kg.DM) & \multicolumn{5}{|c|}{ Chemical components } \\
\hline Dry Matter & 954.3 & 955.4 & 953.9 & 956.4 & 951.2 \\
\hline Ash & 38.0 & 78.5 & 64.8 & 55.2 & 51.2 \\
\hline Crude Protein & 89.9 & 168.2 & 159.1 & 164.4 & 166.9 \\
\hline Ether Extract & 24.9 & 26.7 & 27.9 & 22.4 & 27.6 \\
\hline Neutral Fiber Detergent & 722.5 & 629.6 & 509.6 & 386.0 & 267.4 \\
\hline Acid Fiber Detergent & 429.6 & 372.8 & 285.9 & 208.0 & 127.2 \\
\hline Lignin & 49.1 & 43.7 & 37.3 & 31.8 & 25.8 \\
\hline Cellulose & 293.2 & 259.8 & 197.6 & 142.8 & 89.6 \\
\hline Hemicellulose & 293.0 & 256.8 & 223.7 & 178.0 & 140.2 \\
\hline Fibrous carbohydrates & 671.1 & 581.0 & 465.1 & 337.7 & 223.5 \\
\hline Total carbohydrates & 817.3 & 735.7 & 764.6 & 754.0 & 746.3 \\
\hline Non fibrous carbohydrates & 146.2 & 154.7 & 299.5 & 416.3 & 522.8 \\
\hline Total digestible nutrients & 280.1 & 344.6 & 453.9 & 593.9 & 723.6 \\
\hline TDN:CP & 3.12 & 2.04 & 2.85 & 3.61 & 4.33 \\
\hline
\end{tabular}

${ }^{1}$ Centesimal concentration in relation to the concentrated ration of the diets.

${ }^{2}$ Composition: $\mathrm{Ca}-7.5 \%$; $-3 \%$; Fe -16.500 ppm; $\mathrm{Mn}-9.750$ ppm; $\mathrm{Zn}-35.000$ ppm, I - 1.000 ppm; Se - 225 ppm; Co - 1.000 ppm.

Source: Elaboration of the authors.

\section{Nutrients digestibility}

Digestibility trials were conducted in eight times throughout the experiment to determine the ME of the diet. Indigestible neutral detergent fiber (iNDF) was used as a marker to estimate fecal dry matter excretion, as described by Casali et al. (2008). Feces were collected for three consecutive days every 15 days during the experimental period, at 8 a.m. on the first day, at noon on the second day, and at 4 p.m. on the third day.

The amount of iNDF in the fecal samples, orts, concentrates and Tifton 85 hay were obtained through waste in situ incubations over a period of 240 hours in the rumen of a cow receiving a diet of Tifton 85 hay and concentrates based on corn grain, soybean meal, urea, limestone, dicalcium phosphate, sodium chloride and mineral premix. The roughage:concentrate ratios were 60:40. Incubation was used for nylon bags with porosity of $50 \mu \mathrm{m}$ and a ratio of $15 \mathrm{mg}$ per $\mathrm{cm}^{2}$ of sample bag, totaling three samples per $\mathrm{g}$ of bags, according to the methodology described by McDonald and Orkov (1979). After this period, the bags with the incubation residues were washed in water until it became totally clear. Subsequently, they were boiled for 1 hour in a neutral detergent solution (VAN SOEST; ROBERTSON, 1985). The remains were weighed and considered to be the iNDF (CASALI et al., 2008). 
The dietary digestible energy (DE) was estimated to be $4.409 \mathrm{Mcal} / \mathrm{kg}$ of TDN (Total digestible nutrients, according to WEISS, 1999), and DE was converted to metabolizable energy (ME) using an efficiency of $82 \%$ (NRC, 2000).

\section{Performance and slaughter procedures}

Animals were weighed weekly to calculate average daily gain (ADG). When the BW mean for a particular dietary treatment reached $25 \mathrm{~kg}$, the animals were slaughtered. One animal from the group with the lowest dietary energy concentration (0.96 Mcal $/ \mathrm{kg}$ DM of ME) was also slaughtered at this time. This procedure was carried out for each group until all the animals were slaughtered. Before slaughter, shrunk body weight (SBW) was measured as the BW after 18 hours of food and water fasting. At slaughter, lambs were stunned using a cash knocker and killed by exsanguination from jugular vein by using conventional procedures.

Blood was weighed and sampled. The gastrointestinal tract was weighed full, then emptied, washed out and, after draining, weighed again together with the organs and other body parts (carcass, head, skin, blood, full paw and tail). The body was separated into individual components, which were weighed separately. These included the internal organs (liver, heart, bladder, kidneys, reproductive tract and spleen, being combined lung + trachea and tongue + esophagus), the cleaned digestive tract (rumen, reticulum, omasum, abomasum, and the small and large intestines) and fats (omental, perirenal, mesenteric and heart fats). Empty body weight (EBW) was computed as SBW at slaughter minus digestive tract contents. All carcasses were weighed hot (approximately 1 hour after collection) and then cooled $\left(-4^{\circ} \mathrm{C}\right)$ for approximately 24 hours. After 24 hours of cooling, the chilled carcasses were weighed again and then longitudinally halved with a band saw.

\section{Chemical analysis}

Forage, concentrate and orts composited samples were dried at $55^{\circ} \mathrm{C}$, for $72 \mathrm{~h}$, in a forced air oven, then grounded in a knife mill with 1-mm screen (Wiley mill, Arthur H. Thomas, Philadelphia, PA, USA). The samples were analyzed for contents of dry matter (DM; AOAC, 1990; method number 930.15), ash (Ash; AOAC, 1990; method number 924.05), crude protein (CP; AOAC, 1990; method number 984.13), ether extract (EE; AOAC, 1990; method number 920.39) and acid detergent fiber (ADF; VAN SOEST; ROBERTSON; LEWIS, 1991). To analyze the neutral detergent fiber (NDF), the samples were treated with thermostable alpha amylase without using sodium sulfite, corrected for residual ash (MERTENS, 2002) and for residual nitrogenous compounds (LICITRA; HERNANDEZ; VAN SOEST, 1996).

The content of total carbohydrates (TC) was calculated using the expression recommended by Sniffen, O'Connor and Van Soest (1992): TC $(\%)=100-(\% \mathrm{CP}+\% \mathrm{EE}+\%$ ash $)$. Non fibrous carbohydrates (NFC) were calculated from equation adapted from Weiss (1999), in which: NFC (\%) = $100-(\%$ NDFap $+\% \mathrm{CP}+\% \mathrm{EE}+\%$ ash $)$. For the concentrates, because of the presence of urea in their constitution, NFC was calculated from adapted equation by Hall (2000), in which: NFC = $100-$ $[(\% \mathrm{CP}-\% \mathrm{CP}$ derived from urea $+\%$ of the urea $)$ $+\%$ NDFap $+\%$ EE $+\%$ ash]. The total digestible nutrients (TDN) were calculated by using the following equation by Weiss (1999): TDN: (CP intake - fecal CP $)+($ NDF intake - fecal NDF $)+$ $(\mathrm{NFC}$ intake - fecal NFC $)+[2.25 \times($ EE intake fecal EE)]. 


\section{Statistical analysis}

The experimental design was a randomized block (initial body weight) with five treatments, according to the mathematical model Yij $=\mu+\alpha i+$ $\beta j+$ eij, where: $Y i j=$ value observed in the plot that received treatment $\mathrm{i}$ in block $\mathrm{j} ; \mu=$ general average of the population; $\alpha i=$ effect of treatment $i=1,2,3$, 4,$5 ; \beta \mathrm{i}=$ effect of the block $\mathrm{j}=1,2,3,4,5,6,7,8$; $\mathrm{eij}=$ random error.

The statistical analyses were performed using PROC GLM SAS version 9.0 (SAS, 2003). Analysis of variance was carried out and an orthogonal partition of the sum of the square of treatments into linear, quadratic and cubic degree effects were obtained. The regression equation was adjusted when 0.05 significance was observed, using PROC REG SAS version 9.0.

\section{Results and discussion}

\section{Nutrient digestibility}

The nutrient intake were presented in Camilo et al. (2012), that observed the increase in ME levels in diets influences nutrient intake and feeding behaviour of Morada Nova lambs during the growing period. As the levels of ME increase in the diet, values of evaluated nutrient digestibility coefficients presented linear increase $(\mathrm{P}<0.05$; Table 3). High correlations between OM digestibility and energy content of food or diets have been reported by AFRC (1993) and also can be observed in this study.

Table 3. Nutrients apparent digestibility in sheep fed different levels of metabolizable energy.

\begin{tabular}{lccccccccc}
\hline & \multicolumn{4}{c}{ ME level in diet (Mcal/kg DM) } & \multirow{2}{*}{ SEM } & \multicolumn{3}{c}{ Effect degree } \\
\cline { 2 - 4 } \cline { 8 - 9 } Item(\%) & 0.96 & 1.28 & 1.72 & 2.18 & 2.62 & & $\mathrm{~L}$ & $\mathrm{Q}$ & $\mathrm{C}$ \\
\hline $\mathrm{DM}^{\mathrm{a}}$ & 33.48 & 34.96 & 48.85 & 64.45 & 72.45 & 2.75 & $<0.0001$ & 0.5868 & 0.0474 \\
$\mathrm{OM}^{\mathrm{b}}$ & 34.34 & 37.40 & 52.67 & 67.96 & 74.93 & 2.77 & $<0.0001$ & 0.8328 & 0.0292 \\
$\mathrm{CP}^{\mathrm{c}}$ & 32.50 & 58.56 & 62.65 & 64.17 & 70.38 & 2.27 & $<0.0001$ & $<0.0001$ & $<0.0001$ \\
$\mathrm{EE}^{\mathrm{d}}$ & 40.31 & 32.58 & 53.83 & 59.32 & 61.12 & 2.71 & $<0.0001$ & 0.4678 & 0.1047 \\
$\mathrm{NDF}^{\mathrm{e}}$ & 31.59 & 31.30 & 33.57 & 40.69 & 47.91 & 1.33 & $<0.0001$ & 0.0250 & 0.6429 \\
$\mathrm{TC}^{\mathrm{f}}$ & 33.29 & 35.30 & 47.75 & 65.13 & 74.26 & 3.05 & $<0.0001$ & 0.5472 & 0.1834 \\
$\mathrm{FC}^{\mathrm{g}}$ & 25.82 & 29.80 & 31.00 & 34.65 & 35.03 & 1.12 & 0.0046 & 0.5179 & 0.9704 \\
$\mathrm{NFC}^{\mathrm{h}}$ & 23.68 & 35.13 & 68.60 & 83.93 & 90.57 & 4.36 & $<0.0001$ & $<0.0001$ & 0.0205 \\
\hline
\end{tabular}

$\mathrm{SEM}=$ standard error of the mean; $\mathrm{L}=$ linear degree; $\mathrm{Q}=$ quadratic degree; $\mathrm{C}=$ cubic degree

${ }^{\mathrm{a}} \hat{\mathrm{Y}}=5.482+25.842 \mathrm{ME}\left(\mathrm{R}^{2}=0.97\right) \quad{ }^{\mathrm{Y}} \hat{\mathrm{Y}}=18.903+10.297 \mathrm{ME}\left(\mathrm{R}^{2}=0.89\right)$

${ }^{\mathrm{b}} \hat{\mathrm{Y}}=19.592+11.26 \mathrm{ME}\left(\mathrm{R}^{2}=0.93\right) \quad{ }^{\mathrm{f}} \hat{\mathrm{Y}}=2.974+27.336 \mathrm{ME}\left(\mathrm{R}^{2}=0.97\right)$

${ }^{\mathrm{c}} \hat{\mathrm{Y}}=26.512+17.933 \mathrm{ME}\left(\mathrm{R}^{2}=0.70\right) \quad{ }^{\mathrm{g}} \hat{\mathrm{Y}}=21.880+5.373 \mathrm{ME}\left(\mathrm{R}^{2}=0.95\right)$

${ }^{\mathrm{d}} \hat{\mathrm{Y}}=20.875+16.593 \mathrm{ME}\left(\mathrm{R}^{2}=0.85\right) \quad \mathrm{h} \hat{\mathrm{Y}}=-14.753+42.925 \mathrm{ME}\left(\mathrm{R}^{2}=0.95\right)$

Source: Elaboration of the authors.

Increase of the DM digestibility coefficient with increase of concentrate levels could have occurred due to a greater level of non fibrous carbohydrates (NFC) because the corn meal included in these diets had presented a large amount of NFC (Table 1), which can be rapidly digested by rumen microorganisms, therefore increasing DM digestibility. According to Pina et al. (2009), digestibility is the result of the competition between digestion and passage rates and passage rate is positively correlated with DMI. Non fibrous carbohydrates presents digestibility above $90 \%$ and FC close to $50 \%$ (VALADARES FILHO, 1985).

Rokomatu and Aregheore (2006) also related increase of apparent digestibility for DM, OM and 
$\mathrm{CP}$ when concentrate was included in diets for sheep, with values of $71.22,70.63$ and $66.42 \%$, respectively. Mahgoub, Lu and Early (2000), evaluating diets with $2.4,2.5$ and $2.7 \mathrm{Mcal} / \mathrm{kg}$ DM for lambs, observed dry matter digestibility coefficients of $66.9,68.7$ and $73.9 \%$, respectively.

\section{Growth performance and carcass characteristics}

The carcass characteristics evaluated were not influenced by increase on the levels of dietary ME (Table 4). Also, Liméa et al. (2009) did not observed significant effect of increased levels of concentrate on cold carcass weight and biological yield in goat carcass.

Table 4. Growth performance and carcass characteristics of Morada Nova sheep fed different levels of metabolizable energy.

\begin{tabular}{|c|c|c|c|c|c|c|c|c|}
\hline \multirow{2}{*}{ Variable } & \multicolumn{4}{|c|}{ ME level in diet (Mcal/kg DM) } & \multirow{2}{*}{ SEM } & \multicolumn{3}{|c|}{ Effect degree } \\
\hline & 1.28 & 1.72 & 2.18 & 2.62 & & $\mathrm{~L}$ & $\mathrm{Q}$ & $\mathrm{C}$ \\
\hline Initial weight $(\mathrm{kg})$ & 11.30 & 11.58 & 12.71 & 12.59 & - & - & - & - \\
\hline Final weight $(\mathrm{kg})$ & 25.00 & 25.44 & 24.94 & 25.91 & - & - & - & - \\
\hline Shrunk body weight $(\mathrm{kg})$ & 22.75 & 23.34 & 23.64 & 24.65 & 0.54 & 0.1451 & 0.8175 & 0.7925 \\
\hline Average weight gain $(\mathrm{g} / \text { day })^{\mathrm{a}}$ & 78.31 & 94.95 & 112.19 & 135.98 & 5.04 & $<0.0001$ & 0.5904 & 0.7963 \\
\hline Empty body weight (kg) & 19.02 & 19.94 & 20.58 & 21.25 & 0.53 & 0.0775 & 0.8889 & 0.9272 \\
\hline Hot carcass weight (kg) & 11.01 & 11.12 & 11.76 & 12.18 & 0.34 & 0.1436 & 0.8064 & 0.7999 \\
\hline Cold carcass weight $(\mathrm{kg})$ & 10.51 & 10.71 & 11.30 & 11.60 & 0.33 & 0.1568 & 0.9357 & 0.8100 \\
\hline Loss by cooling $(\mathrm{kg})$ & 0.50 & 0.41 & 0.46 & 0.50 & 0.12 & 0.7694 & 0.0484 & 0.2727 \\
\hline Biological yield (\%) & 57.50 & 55.68 & 57.00 & 57.56 & 0.63 & 0.8012 & 0.3886 & 0.5262 \\
\hline Digestive tract weight $(\mathrm{kg})$ & 5.00 & 4.71 & 4.31 & 4.58 & 0.11 & 0.099 & 0.2178 & 0.4405 \\
\hline Digestive tract content $(\mathrm{kg})$ & 3.73 & 3.40 & 3.06 & 3.39 & 0.11 & 0.1577 & 0.1577 & 0.5070 \\
\hline
\end{tabular}

$\mathrm{SEM}=$ standard error of the mean; $\mathrm{L}=$ linear degree; $\mathrm{Q}=$ quadratic degree; $\mathrm{C}=$ cubic degree ${ }^{\mathrm{a}} \mathrm{Y}=22.567+42.456 \mathrm{EM}\left(\mathrm{R}^{2}=0.89\right)$

Source: Elaboration of the authors.

Values of cold carcass weight and biological yield obtained by Liméa et al. (2009), were close to the ones presented in this study, with mean equal to $10.72 \mathrm{~kg}$ and 58.75 , respectively. Observed average weight of hot carcass $(11.51 \mathrm{~kg})$ was lower than the one presented by Jacques, Berthiaume and Cinq-Mars (2011). Studying the effect of roughage:concentrate ration on the carcass yields (hot, cold and biological) of Morada Nova lambs, Gonzaga Neto et al. (2006) found higher yields as the concentrate level and dietary ME increased, which has not observed in this study.

Influence of BW on carcass dressing can be changed by gastrointestinal content, which in turn is influenced by number of hours of fast to which animals are subjected and by the kind of the diet.
Considering that all animals were subjected to solid fast for 18 hours and slaughtered with approximately $25 \mathrm{~kg}$ of BW, emptying of gastrointestinal tract might have be slower in treatments with higher proportion of roughage, before measurement of BW. Such results are in agreement with Preston and Willis (1974) and ARC (1980), who stated that addition of concentrate in the diet reduces content of gastrointestinal tract, thus, resulting in increasing values of EBW as energy level in the diets increased.

The values of average weight gain increased linearly with addition in the levels of ME in the diets, with the diet with $2.62 \mathrm{Mcal} / \mathrm{kg}$ DM presenting ADG of $135.98 \mathrm{~g} /$ day.

The diets were formulated to provide daily weight gains of $200 \mathrm{~g}$, which was not achieved in 
any of the treatments, even with the highest level of ME in the diet (2.62 Mcal/kg DM). This fact can be attributed to the lower genetic potential for weight gain by Morada Nova breed compared with other breeds more specialized for meat production. However, for meat production systems adopted in Northeast of Brazil, this result can be satisfactory and show the advantage of energy supplementation of animals under traditional systems, a strategy that should be adopted by local lamb producers. There was a trend of improving feed conversion with the increase in ME levels as it has been observed for Omani sheep (MAHGOUB; LU; EARLY, 2000).

In Brazil, there will be consequent improvements in models of energy utilization and opportunities for increasing productivity through the selection of animals that are more efficient as a result of lower maintenance needs.

\section{Conclusions}

Increment of the energy level in diets influences the digestibility of nutrients and the daily weight gain of Morada Nova lambs during the growing period, without changing carcass traits.

\section{Acknowledgments}

The authors wish to thank the Conselho Nacional de Pesquisa e Desenvolvimento Científico e Tecnológico (CNPq) and Banco Nordeste do Brasil for financial support.

\section{References}

AGRICULTURALAND FOOD RESEARCH COUNCIL - AFRC. Energy and protein requirements of ruminants. Wallingford: CAB International, 1993. 159 p.

AGRICULTURAL RESEARCH COUNCIL - ARC. The nutrient requirements of ruminants livestock. London: Commonwealth Agricultural Bureaux. 1980. 351 p.
ASSOCIATION OF OFFICIAL ANALYTICAL CHEMISTS - AOAC. Official methods of analysis. 6. ed. Arlington, Virgínia: Ed. Keneth Helrich, 1990. 1298 p.

CAMILO, D. A.; PEREIRA, E. S.; PIMENTEL, P. G.; OLIVEIRA, R. L.; CANDIDO, M. J. D.; COSTA, M. R. F. C.; AQUINO, R. M. S. Intake and feeding behaviour of Morada Nova lambs fed different energy levels. Italian Journal of Animal Science, Pavia, v. 11, n. 1, p. 13-19, 2012.

CASALI, A. O.; DETMANN, E.; VALADARES FILHO, S. C.; PEREIRA, J. C.; HENRIQUES, L. T.; FREITAS, S. G.; PAULINO, M. F. Influência do tempo de incubação e do tamanho de partículas sobre os teores de compostos indigestíveis em alimentos e fezes bovinas obtidos por procedimentos in situ. Revista Brasileira de Zootecnia, Viçosa, v. 37, n. 2, p. 335-342, 2008.

FERNANDES, A. A. O. Genetic and phenotypic parameter estimates for growth, survival and reproductive traits in Morada Nova hair sheep. 1992. PhD. Thesis (Doctor) - Oklahoma State University, USA.

GONZAGA NETO, S.; SILVA SOBRINHO, A. G.; ZEOLA, N. M. B. L.; MARQUES, C. A. T.; SILVA, A. M.A.; PEREIRA FILHO, J. M.; FERREIRA, A. C. D. Características quantitativas da carcaça de cordeiros deslanados Morada Nova em função da relação volumoso: concentrado na dieta. Revista Brasileira de Zootecnia, Viçosa, v. 35, n. 4, p. 1487-1495, 2006.

HALL, M. B. Calculation of non-structural carbohydrate content of feeds that contain non-protein nitrogen. Gainesville, USA: University of Florida, 2000. A25-A34. (Bulletin, n. 339).

JACQUES, J.; BERTHIAUME, R.; CINQ-MARS, D. Growth performance and carcass characteristics of Dorset lambs fed different concentrates: Forage ratios or fresh grass. Small Ruminant Research, Amsterdam, v. 95, n. 2, p. 113-119, 2011.

LICITRA, G.; HERNANDEZ, T. M.; VAN SOEST, P. J. Standardization of procedures for nitrogen fractionation of ruminant feeds. Animal Feed Science and Technology, California, v. 57, n. 4, p. 347-358, 1996.

LIMÉA, L.; BOVAL, M.; MANDONNET, N.; GARCIA, G.; ARCHIMÈDE, H.; ALEXANDRE, G. Growth performance, carcass quality, and noncarcass components of indigenous Caribbean goats under varying nutritional densities. Journal of Animal Science, Madison, v. 87, n. 11, p. 3770-3781, 2009. 
MAHGOUB, O.; LU, C. D.; EARLY, R. J. Effects of dietary energy density on feed intake, body weight gain and carcass chemical composition of Omani growing lambs. Small Ruminant Research, v. 37, n. 1-2, p. 35-42, 2000.

McDONALD, P.; ORSKOV, E.R. The estimation of protein degradability in the incubation measurements weighted according to rate of passage. Journal of Agricultural Science, Cambridge, v. 92, n.2, 499-503, 1979.

McMANUS, C.; PAIVA, S. R.; ARAÚJO, R. O. Genetics and breeding of sheep in Brazil. Revista Brasileira de Zootecnia, Viçosa, v. 39, p. 236-246. 2010. Suplemento Especial.

MERTENS, D. R. Gravimetric determination of amylasetreated neutral detergent fiber in feeds with refluxing in beaker or crucibles: collaborative study. Journal of AOAC International, Gaithersburg, MD, USA, v. 85, n. 6, p. 1217-1240, 2002.

NATIONAL RESEARCH COUNCIL - NRC. Nutrient requirements of beef cattle. $8^{\text {th }}$ ed. National Academy Press, Washington, DC, USA, 2000. 248 p.

. Nutrient requirements of small ruminants: sheep, goats, cervids and newworld camelids. National Academy Press, Washington, DC, USA, 2007. 384 p.

PINA, D. S.; VALADARES FILHO, S. C.; TEDESCHI, L. O.; BARBOSA, A. M.; VALADARES, R. F. D. Influence of different levels of concentrate and ruminally undegraded protein on digestive variables in beef heifers. Journal of Animal Science, Madison, v. 87, n. 3, p. 10581067, 2009.

PRESTON, T. R.; WILLIS, M. B. Intensive beef production. $2^{\text {nd }}$ ed. Oxford, England: Pergammon Press Ltd., Headington Hill, 1974. 567 p.
ROKOMATU, I.; AREGHEORE, E. M. Effects of supplementation on voluntary dry matter intake, growth and nutrient digestibility of the Fiji Fantastic sheep on a basal diet of Guinea grass (Panicum maximum). Livestock Science, Foulum, v. 100, n. 2, p. 132-141, 2006.

SAS SYSTEM FOR WINDOWS, Release 9.1 (TS1M3). SAS Institute Inc. Administrator Guide for $\mathrm{SAS}{ }^{\circledR}$ 9.1.3 Foundation for Microsoft ${ }^{\circledR W i n d o w s}{ }^{\circledR}$.Cary, NC: SAS Institute Inc., 2003. 78 p.

SNIFFEN, C. J.; O'CONNOR, J. D.; VAN SOEST, P. J. A net carbohydrate and protein system for evaluating cattle diets: carbohydrate and protein availability. Journal of Animal Science, Madison, v. 70, n. 11, p. 3562-3577, 1992.

VALADARES FILHO, S. C. Digestão total e parcial da matéria seca e carboidratos em bovinos e bubalinos. 1985. Tese (Doutorado em Zootecnia) - Universidade Federal de Viçosa, Viçosa.

VAN SOEST, P. J. Symposium on factors influencing the voluntary intake in relation to chemical composition and digestibility. Journal of Animal Science, Madison, v. 24, n. 3, p. 834-843, 1965.

VAN SOEST, P. J.; ROBERTSON, J. B. Analysis of forages and fibrous foods. AS 613 Manual, Department of Animal Science. Cornell University, Ithaca, NY, USA. 1985.

VAN SOEST, P. J.; ROBERTSON, J. B.; LEWIS, B. A. Methods for dietary fiber, neutral-detergent fiber and nonstarch polysaccharides in relation to animal nutrition. Journal of Dairy Science, Madison, v. 74, n. 10, p. 35833597, 1991.

WEISS, W. P. Energy prediction equations for ruminant feeds. In: CORNELL NUTRITION CONFERENCE FOR FEED MANUFACTURERS, 61., 1999, Ithaca, USA. Proceedings... Ithaca: Cornell University, 1999. p. 176-185. 
